Article

\title{
Impacts of Microclimate Conditions on the Energy Performance of Buildings in Urban Areas
}

\author{
Kavan Javanroodi ${ }^{1, *}$ and Vahid M. Nik ${ }^{1,2,3}$ \\ 1 Division of Building Physics, Department of Building and Environmental Technology, Lund University, \\ SE-223 63 Lund, Sweden \\ 2 Division of Building Technology, Department of Civil and Environmental Engineering, Chalmers University \\ of Technology, SE-412 96 Gothenburg, Sweden \\ 3 Institute for Future Environments, Queensland University of Technology, Box 2434, Brisbane, \\ QLD 4001, Australia \\ * Correspondence: kavan.javanroodi@byggtek.lth.se; Tel.: +46-736-517-924
}

Received: 30 June 2019; Accepted: 14 August 2019; Published: 16 August 2019

check for updates

\begin{abstract}
Urbanization trends have changed the morphology of cities in the past decades. Complex urban areas with wide variations in built density, layout typology, and architectural form have resulted in more complicated microclimate conditions. Microclimate conditions affect the energy performance of buildings and bioclimatic design strategies as well as a high number of engineering applications. However, commercial energy simulation engines that utilize widely-available mesoscale weather data tend to underestimate these impacts. These weather files, which represent typical weather conditions at a location, are mostly based on long-term metrological observations and fail to consider extreme conditions in their calculation. This paper aims to evaluate the impacts of hourly microclimate data in typical and extreme climate conditions on the energy performance of an office building in two different urban areas. Results showed that the urban morphology can reduce the wind speed by $27 \%$ and amplify air temperature by more than $14 \%$. Using microclimate data, the calculated outside surface temperature, operating temperature and total energy demand of buildings were notably different to those obtained using typical regional climate model (RCM)-climate data or available weather files (Typical Meteorological Year or TMY), i.e., by $61 \%, 7 \%$, and $21 \%$, respectively. The difference in the hourly peak demand during extreme weather conditions was around $13 \%$. The impact of urban density and the final height of buildings on the results are discussed at the end of the paper.
\end{abstract}

Keywords: urban microclimate; extreme weather conditions; energy performance; urban areas; CFD simulations

\section{Introduction}

According to the UN [1], about $55 \%$ of the world's population live in cities, and this number is projected to increase to over $67 \%$ in 2050. In developed countries (Europe and Northern America), the urban population is even higher $(78 \%)$ and expected to increase to $81 \%$ in 2050 [2]. This rapid urbanization has resulted in more complex urban morphologies with a wide range of built density, layout, and forms. This complexity in urban morphologies has created several challenges in designing bioclimatic buildings that support the progression toward climate-resilient urban neighborhoods. Global energy consumption in urban areas is more than $70 \%$ [3] as a result of the convoluted microclimate conditions in cities, with most of this driven by the demands of the building sector [4]. Office buildings (including 23\% of nonresidential buildings) are responsible for more than $48 \%$ of the annual energy demand (heating and cooling) in urban areas [5,6]. It is commonly accepted that urban 
microclimate conditions have a significant impact on urban climates $[7,8]$, urban comfort $[9,10]$, and the energy performance of buildings [11,12]. At the urban microscale level, the average wind speed is lower, with more complex flow patterns as compared to rural areas [13]. Moreover, due to the urban heat island (UHI) effect, the average air temperature is higher in urban areas [14]. The fluctuations in wind speed and air temperature affect a wide range of engineering applications in urban areas and buildings.

Hence, these impacts tend to be underestimated when energy performance simulation (EPS) studies adopt widely-available climatic data such as weather files with an EPW (EnergyPlus Weather file) format. These weather files are usually based on locally recorded weather data for typical years, such as the Typical Meteorological Year (TMY) and the Weather Year for Energy Calculation (WYEC), to represent the long-term average climate conditions at a location [15]. However, these weather files fail to represent local microscale data and extreme weather conditions, which can introduce large peak loads and cause higher total energy demand on average [16]. Due to the budget and time limitations of construction projects, it is not possible to generate weather datasets by means of Computational Fluid Dynamics (CFD) simulations or long-term local measurements for a whole urban area with hourly time-step. On the other hand, architects and urban designers frequently make use of commercial building energy simulation tools in the early stage design process; thus, it would be helpful if they could adopt more design-based methods and user-friendly procedures based on existing simulation engines. Hence, researchers and energy experts need to develop a method to normalize widely-available weather files in regular EPS tools based on local microclimate conditions in relation to the urban morphology. These normalized weather files can be easily adopted by designers to obtain more accurate estimations of microclimate conditions and, consequently, more reliable energy demand calculations.

The novelty of this paper is that it investigates the fluctuations of seven main climate variables (wind speed, wind direction, air temperature, air pressure, relative humidity, global radiation, and cloud coverage) at microscale with an hourly time-step to generate microclimate weather data through a comprehensive CFD study coupled with energy performance simulations. Moreover, a detailed comparison is made between mesoscale weather files and microclimate data in terms of surface temperature, operative temperature, and energy demand. The paper is structured as follows: First, the numerical model and adopted weather datasets are discussed thoroughly; then, the inputs and setting for CFD and energy performance simulations are presented in the Methodology section. Third, the results of the CFD simulations and generated microclimate weather data for energy simulation are discussed in Section 3.1. Using fifteen sets of 24-h continuous weather data, the results of surface temperature, operative temperature and energy demand for both urban models are assessed. Finally, a summary of the main findings, with the focus on urban design strategies, is presented in the Conclusions section.

\section{Background}

It is crucial to develop a method that considers microclimate data in both typical and extreme conditions in regular EPS studies as it affects several engineering applications in buildings. In this regard, there have been some attempts to develop a multiscale method that takes into account microscale data by comparing the results of high-resolution metrological mesoscale models (such as Weather Research and Forecasting (WRF) model [17] and remote sensing methods [18]) at the near-surface ground level $[19,20]$. These models [21] have usually focused on non-urban areas or have not focused on evaluating the energy performance of urban areas, and consequently, they cannot be directly applied in the current commercial BES tools. A comprehensive review on the main approaches for modeling and simulating urban areas and microclimate conditions can be found in [22]. There are several challenges in modeling and simulating urban microclimate conditions, even though it is commonly accepted that urban morphology has a major impact on microclimate conditions [23]. To overcome the limitations and complexities of modeling urban microclimates, experimental methods 
(for models with low temporal and spatial resolutions) [24], mathematical/analytical methods [25], numerical methods [26] or a combination of these methods [27] have usually been adopted in the current literature. Numerical methods, due to their flexibility and accuracy in predicting local-scale phenomena in urban areas, have been widely used to study microclimate conditions and urban wind comfort [28]. Several research works have adopted numerical methods to study microclimate conditions by means of computational fluid dynamics (CFD) with detailed approaches (for small-scale cases or a limited number of iterations) [29] or with more simplified approaches (for larger urban areas and a higher number of iterations) [30]. It is commonly accepted that the urban geometry or form can change microclimate conditions [31]. Thus, most studies have used generic configurations [32] or real-site cases [33] as urban areas, and some have adopted a combination of these models [34]. The main factors in the urban microclimate that have been investigated include air temperature [35], surface temperature [36], solar radiation [37], wind flow variations [38], and air humidity [39]. Many works have studied the UHI effect on the energy performance of buildings [40,41] and its impacts on higher cooling demand in cold regions and lower heating demand in hot-arid regions $[42,43]$ in urban areas.

Except for a few studies [44], research on wind flow at the urban scale is mostly limited to urban comfort studies [45]; these have evaluated a limited range of constant average values [46] or urban wind at the pedestrian level around buildings regardless of energy demand simulations [47]. There are several studies which have used coupled CFD-BES models to evaluate microclimate conditions considering wind and temperature variations [48]. However, in these studies urban areas are mostly defined as a shading object or obstacle on the building in the regular energy simulation engines. In other words, the fluctuations of the local microclimate data are ignored in the process of urban morphology modeling and weather data generation. Particularly in regions with several frequent extreme wind conditions, these impacts can induce undesired variations in the average and peak energy loads. In this regard, this paper aims to evaluate the microclimate conditions of two detailed urban areas by means of CFD simulations with an hourly time-step to assess the outside surface temperature, operative temperature, and total energy demand of buildings. The urban models represent the major high- and low-density areas of Stockholm. The surface temperature, operative temperature, and energy demand of the buildings in the urban models were evaluated adopting fifteen 24-h continuous weather data based on typical and extreme wind conditions out of three sources, including a regular TMY file, a synthesized metrological regional climate model (RCM)-climate dataset, and microclimate data, using the results of the CFD simulations.

\section{Methodology}

This section gives an overview on the urban models as well as energy performance evaluations. Section 3.1 discusses the process of generating two high-density and low-density urban models to represent major urban morphologies of Stockholm. Section 3.2 presents the adopted methods to generate hourly RCM-climate weather datasets for typical and extreme conditions in additions to extracted TMY-based weather files. Finally, the defined computational domain and boundary conditions of CFD simulations and EPS inputs are presented in Section 3.3.

\subsection{Modeling Urban Areas}

Two simplified urban models in two areas with high and low densities were generated based on a technique called "building modular cell" (BMC), in accordance with a comprehensive parameter, namely, urban density (including layout density, building form, and height). The BMC technique is based on an $8 \times 8 \times 8 \mathrm{~m}$ cube as the basic module. Using this module, thousands of building forms and urban areas were generated and verified to assess the impacts of urban morphology on energy demand and microclimate conditions. The generated and verified urban morphologies are hypothetical configurations based on statistics out of real urban areas such as various site coverages, overall forms, and urban patterns. In this study, based on major urban morphology parameters, three urban layouts were selected out of this database to be considered as urban models. For a more detailed description of 
this technique, readers are referred to [49]. These urban models consist of eight building blocks as urban roughness and a public green space in the top-left corner of the model. For the high-/low-density urban models, total site coverage of $87.5 \%$ and $35.8 \%$ are defined to generate seven building blocks around the central twelve-story buildings. These models were generated using a Grasshopper algorithm with similar streets (width $=30.9 \mathrm{~m}$ ) and urban canopies (width $=6 \mathrm{~m}$ ) between buildings $(40 \%$ of the total area of the site is open spaces). The total area of each model is $24,000 \mathrm{~m}^{2}$ with similar physical properties. The distinct forms of buildings in each model with rectangular geometries are designed to identify complex wind flow and air temperature profiles around them. The number of urban models is limited to two due to required computational power for hourly-resolution CFD simulations for three days. Figure 1a,b shows the 3D visualization of low-density (LD) and high-density (HD) urban models in this study. The schematic section of the defined layers of the generated urban areas (based on definitions in [13]) is illustrated in Figure 1c.
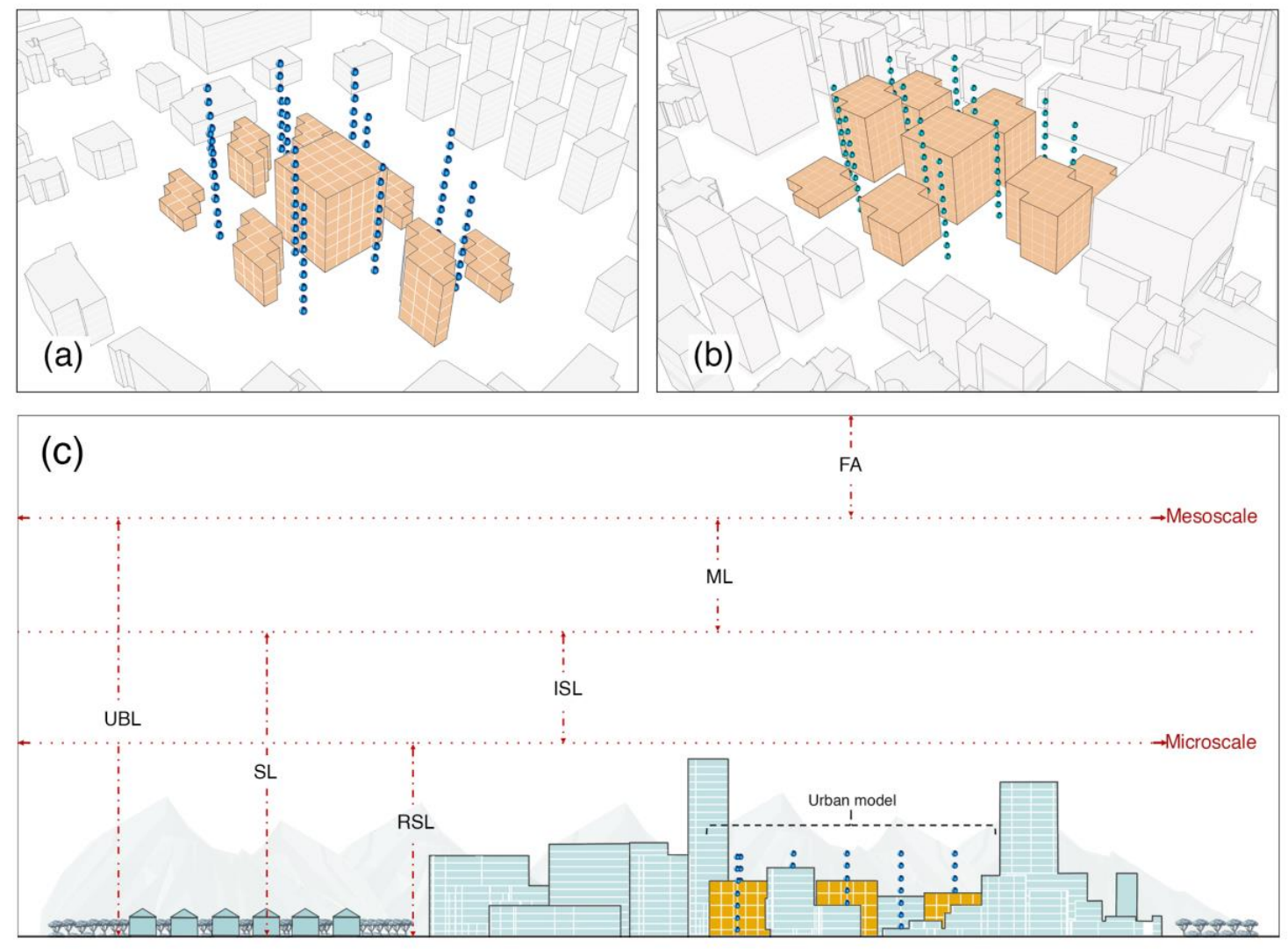

Figure 1. 3D visualization of generated urban models in this study: (a) low-density urban model (LD), (b) high-density urban model (HD), (c) schematic section of the generated urban models: RSL: roughness sublayer; SL: surface layer; UBL: urban boundary layer; ISL: inertial sublayer, ML: mixed layer; FA: free atmosphere.

\subsection{Weather Data Sets}

For metrological weather data, three 24-h continuous data were generated based on a method introduced by Nik [50] to synthesize typical and extreme weather files based on the outdoor temperature, to be used in energy simulations. In this method, the representative and extreme months using Finkelstein-Schafer statistics are selected and verified for hygrothermal simulations [51]. In this paper, a similar logic was adopted based on the wind speed as the main indicator, instead of temperature to synthesize meteorological years with typical and extreme high and low wind speeds. In addition to wind speed, four other climate variables, including air temperature, wind direction, global radiation (direct and indirect), and cloud coverage, were combined to create weather data with an hourly time 
step. Thus, these typical and extreme weather conditions are divided into three sets of typical, high, and low wind speeds and synthesized for the 30-year period of 2010-2039, considering six weather scenarios simulated by the RCA4 regional climate model (RCM) with a spatial resolution of $12.5 \mathrm{~km}$.

To consider microclimate conditions with the minimum number of simulations, one typical and two extreme days were selected from each extreme year. In this regard, 24-h continuous data with typical average wind speed from the year with typical average wind speed, to be called 'typical wind speed' or 'TWS' (19 February), 24-h continuous data with the highest average wind speed from the year with the highest wind speed, to be called 'highest wind speed' or 'HWS' (13 January), and 24-h continuous data with the lowest average wind speed from the year with the lowest wind speed, to be called 'lowest wind speed' or 'LWS' (4 October), were collected.

These weather datasets were used as inputs for boundary conditions in the CFD simulations in each hour. In a parallel process, the same period with a similar approach and method were extracted out of TMY weather files with EPW format for EnergyPlus [52] to evaluate the accuracy of the widely available weather files for energy simulation. Thus, three 24 -h continuous data in the same dates were generated out of the TMY files for Stockholm. For example, in low wind conditions, the weather data of 4 October were extracted. The weather data in these three days in the RCM and TMY files are notably different. In other words, typical and extreme low and high wind conditions in the TMY file occur on different days. Thus, to examine the accuracy of the TMY file in predicting typical and extreme conditions, the same logic used to generate RCM files was adopted to extract three other weather files based on absolute typical and extreme low and high wind conditions out of TMY files. These three 24-h continuous data based on the TMY file for typical wind speed or 'TMY-Typ' (14 September), the highest wind speed or 'TMY-Max' (13 January), and the lowest wind speed or 'TMY-Min' (17 November) were generated. In total, six 24-h continuous weather data out of TMY files as well as three weather datasets from synthesized datasets as mesoscale data were generated. Figure 2 shows the boxplot of wind direction frequency in the generated RCM and TMY weather data. The typical and extreme low and high weather data out of RCM data were used as inputs for simulating microclimate conditions by means of CFD calculation, which resulted in three microclimate datasets (Section 3.1). Table 1 shows the details of each generated weather data in this study.

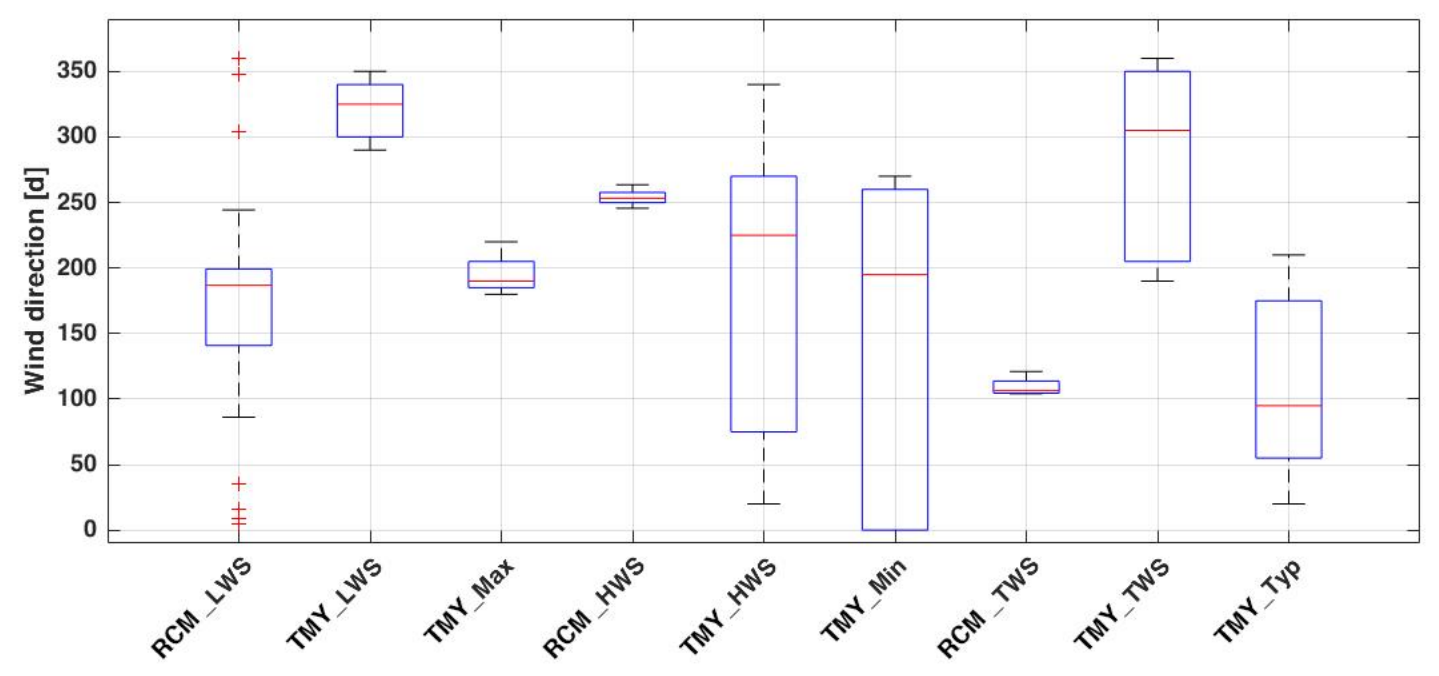

Figure 2. Wind direction frequency in the generated weather datasets. 
Table 1. The details of fifteen generated weather datasets in the study for energy performance simulations (EPS); mesoscale data: regional climate models (RCM) and typical meteorological year (TMY), microscale data: micro in typical and extreme low and high wind conditions.

\begin{tabular}{|c|c|c|c|c|c|c|c|c|}
\hline $\begin{array}{l}\text { Wind } \\
\text { Speed }\end{array}$ & Types & Date & Scale & $\begin{array}{c}\text { Generated Weather } \\
\text { Data }\end{array}$ & STDV & Min & Average & $\operatorname{Max}$ \\
\hline \multirow{5}{*}{ Typical } & \multirow{4}{*}{ TWS } & \multirow{4}{*}{02.19} & Meso & (1) RCM-TWS & 0.37 & 9.91 & 10.61 & 11.06 \\
\hline & & & \multirow{2}{*}{ Micro } & (2) Micro-TWS (LD) & 0.22 & 0.11 & 0.43 & 0.9 \\
\hline & & & & (3) Micro-TWS (HD) & 0.2 & 0.08 & 0.39 & 0.8 \\
\hline & & & Meso & (4) TMY-TWS & 2.62 & 1 & 4.58 & 8.2 \\
\hline & EPW-TYP & 09.14 & Meso & (5) TMY-TYP & 0.93 & 0.5 & 1.65 & 3.1 \\
\hline \multirow{5}{*}{$\begin{array}{l}\text { Extreme } \\
\text { low }\end{array}$} & \multirow{4}{*}{ LWS } & \multirow{4}{*}{10.04} & Meso & (6) RCM-LWS & 0.28 & 0.16 & 0.56 & 1.14 \\
\hline & & & \multirow{2}{*}{ Micro } & (7) Micro-LWS (LD) & 0.26 & 7.6 & 8.12 & 8.33 \\
\hline & & & & (8) Micro-LWS (HD) & 0.29 & 5.31 & 5.82 & 6.36 \\
\hline & & & Meso & (9) TMY-LWS & 0.28 & 0.2 & 0.57 & 1.2 \\
\hline & EPW-Min & 11.17 & Meso & (10) TMY-Min & 0.2 & 0 & 0.25 & 0.5 \\
\hline \multirow{5}{*}{$\begin{array}{c}\text { Extreme } \\
\text { high }\end{array}$} & \multirow{4}{*}{ HWS } & \multirow{4}{*}{01.15} & Meso & (11) RCM-HWS & 0.48 & 12.21 & 13.14 & 14.02 \\
\hline & & & \multirow{2}{*}{ Micro } & (12) Micro-HWS (LD) & 0.3 & 7.98 & 8.57 & 9.16 \\
\hline & & & & (13) Micro-HWS (HD) & 0.2 & 6.45 & 6.95 & 7.29 \\
\hline & & & Meso & (14) TMY-HWS & 0.45 & 12.2 & 13.53 & 14 \\
\hline & EPW-Max & 01.13 & Meso & (15) TMY-Max & 4.46 & 6.2 & 12.55 & 18 \\
\hline
\end{tabular}

\subsection{CFD and EPS}

The calculations in this study are divided into two sections: CFD simulations and EPS. For CFD simulations, in each urban model, ninety-nine calculation points were defined to simulate wind speed and air temperature in different locations of the site. These calculation points are located in eleven critical locations of each model, and in each location, nine points from $2 \mathrm{~m}$ to $66 \mathrm{~m}$ level are defined. The average values of all calculation points are considered as the local microclimate wind speed, air temperature, relative humidity, and air pressure for each hour in the roughness sublayer. To simulate turbulent flow conditions, the standard $\mathrm{k}-\varepsilon$ turbulence model was applied. In this model, $\mathrm{k}$ represents the turbulent kinetic energy equation and $\varepsilon$ represents dissipation of kinetic energy [53]. The adopted model was validated through hundreds of iterations using ANSYS Fluent, Autodesk CFD, and measured data for the numerical models in an earlier work of the authors [49]. In this study, $\sigma_{k}, \sigma_{\varepsilon}, C_{1 \varepsilon}, C_{2 \varepsilon}$, and $C_{\mu}$ as adjustable dimensionless values are set to 1, 1.30, 1.44, 1.92, and 0.09 , respectively. To consider buoyancy effects, the Boussinesq approximation was applied, and the turbulent Prandtl number $\left(P r_{t}\right)$ was considered as 1.0. The standard wall functions for the turbulent flow were considered next to the wall, and heat transfer by radiation was balanced with the heat transfer by convection using a radiation model based on true view factors calculation for geometries. Figure 3 illustrates the considered computations domains for the urban models. For each urban model, wind speed, wind direction, air temperature, global radiation (direct and indirect), and cloud coverage were applied to the defined boundary conditions (top and lateral) in each hour. The average values of all ninety-nine calculation points for wind speed, air temperature, air pressure, and relative humidity were considered as the microclimate data in each hour based on the adopted weather datasets. The results were used to generate three microclimate condition weather data as discussed in the previous section, including 'Micro-TWS', 'Micro -LWS', and 'Micro -HWS' for typical, extreme low, and high conditions, respectively. 


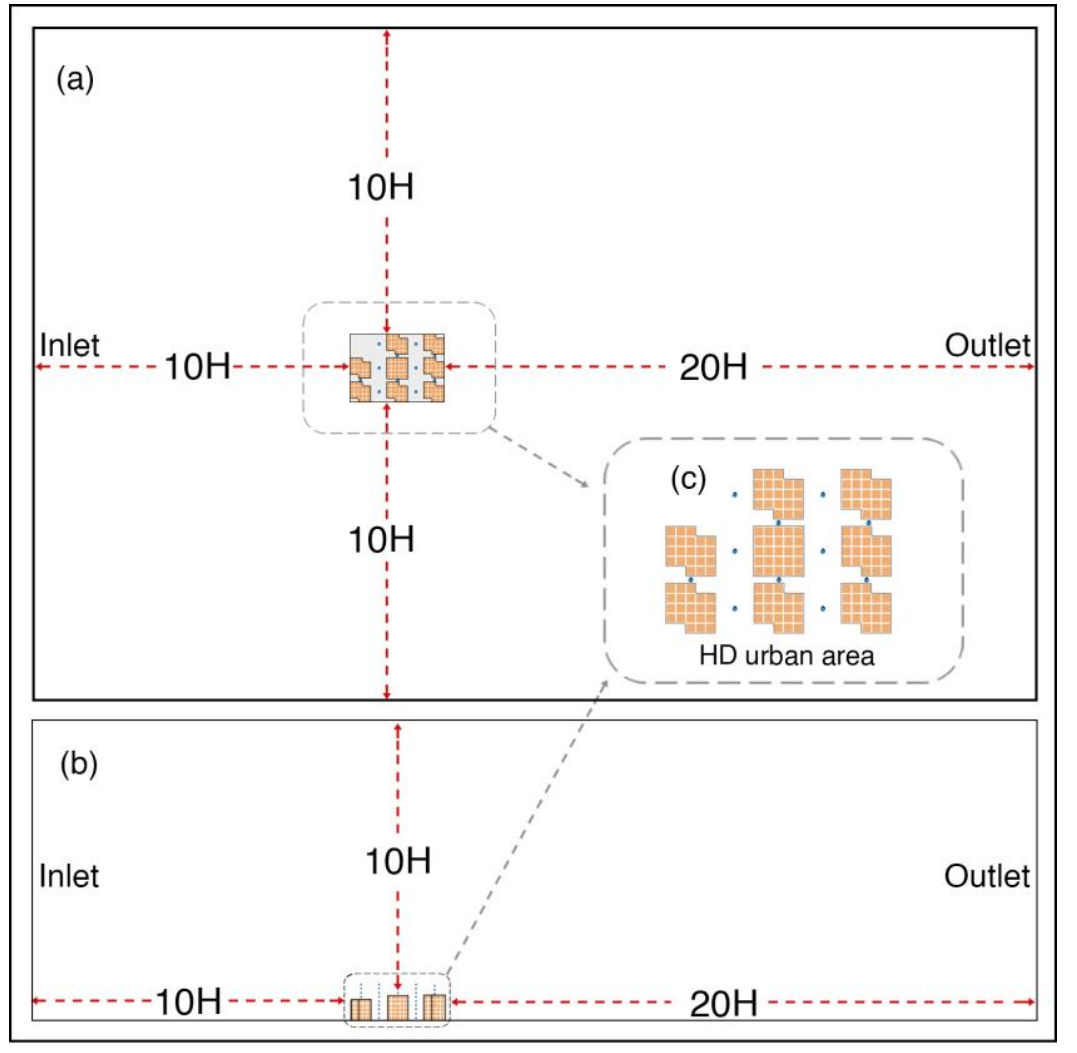

Figure 3. Computational domain defined for the computational fluid dynamics (CFD) simulations. (a) plan view of computational domain; (b) section view of computational domain; (c) HD urban area.

For energy performance simulations (EPS), cooling and heating demand were defined as the sum of the latent and sensible cooling and heating energy of the central twelve-story building through a validated approach in the earlier work of the authors [54]. Each floor consists of a private office zone and a shared space zone. The urban areas were in Rhinoceros/Grasshopper and converted to EnergyPlus models using Diva-for-Rhino and Archsim [55]. The sum of cooling and heating demand was calculated considering heat transfer through external surfaces of the central building as well as internal heat sources and infiltration through windows for fifteen 24-h continuous day weather data. Table A1 shows the parameters and variable considered for EPS based on the optimal values for both urban models.

Figure 4 illustrates the workflow of the paper from generating weather data to the analysis of the results. At the first step, based on the method introduced by Nik [50], the weather data were developed based on the typical and extreme weather conditions of Stockholm. Then, the urban models were generated in Rhinoceros/Grasshopper based on building modular cells or 'BMC' [42]. The models were transferred to Autodesk CFD using Autodesk Inventor to define computational domains and boundary conditions. Adopting mesoscale weather data, the hourly CFD simulations were run for three 24-h continuous days using wind speed, wind direction, air temperature, global radiation, relative humidity, and cloud coverage as the inputs. The urban models were converted to thermal zone using Diva-for-Rhino and Archsim for EnergyPlus engine. Then, the outside surface temperature, operative temperature, and total energy demand of the central building in each urban model were evaluated with an hourly time-step. 


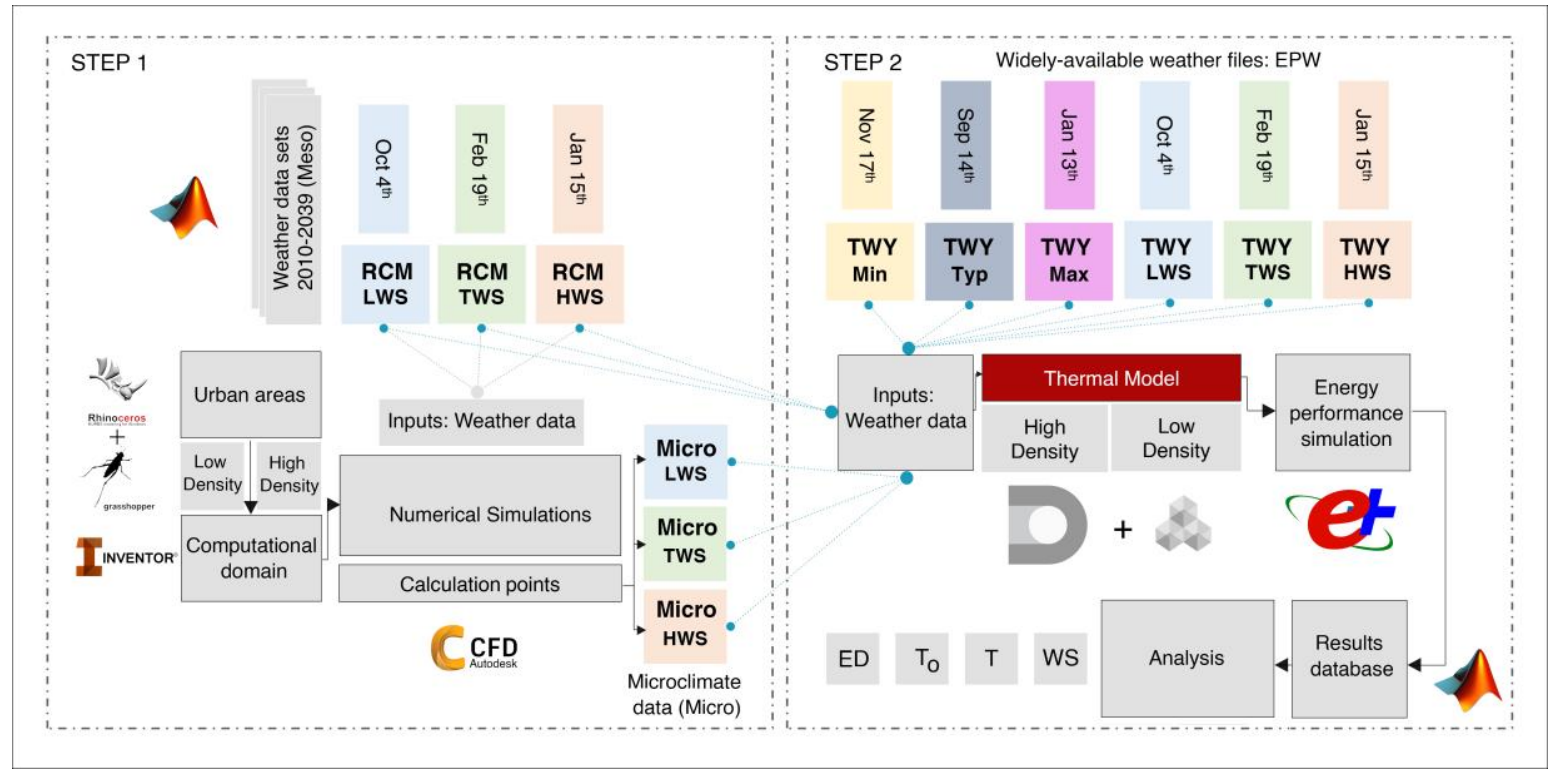

Figure 4. The schematic workflow of the paper.

\section{Results and Discussion}

This section presents an overview of the main findings of the paper in two sections. The results of CFD simulations for microclimate conditions are presented and discussed for wind speed and air temperature in Section 3.1. Then, based on the acquired data, three 24-h continuous weather data are generated based on the adopted synthesized mesoscale weather datasets. In Section 3.2, all generated weather datasets (RCM, Micro, and TMY data for TWS, LWS, and HWS conditions) are applied to the thermal model of the urban areas to simulate the hourly outside surface temperature, operative temperature, and the sum of the energy demand of the central building in each case.

\subsection{CFD Simulations}

Figure 5 shows the hourly air temperature and wind speed out of CFD simulations as microclimate data normalized by input values acquired out of RCM weather datasets. It is clear that the average wind speed in all hours in both urban areas is lower than the input value, while the air temperature in all weather conditions is mostly higher than the input values. The variations of air temperature in all three weather conditions are lower with similar trends, while the fluctuations of average wind speed due to its nature are considerably higher. Due to lower wind flow distribution in the urban fabrics of the HD model, the normalized wind speed is notably lower compared to that of the LD model. In the LD area, the approaching flows towards the windward buildings are distributed into the adjacent urban canopy axis and are directed toward other canopies. The lateral wind flows into the urban area in the LD are lower than into the denser urban area. In HD, higher WS and more intense turbulences are observed in the main streets compared to canopies. During other hours of the day in the HD area, a larger amount of flow approaches the eastern parts of the site, particularly when input wind speed is lower than $1 \mathrm{~m} / \mathrm{s}$. In cases where input wind speed is higher than $1 \mathrm{~m} / \mathrm{s}$, a stagnation point occurs at the façade and rooftop of the windward buildings as obstacles which direct the flow over the urban area at the higher heights and results in higher $\mathrm{T}$ at lower surfaces. 

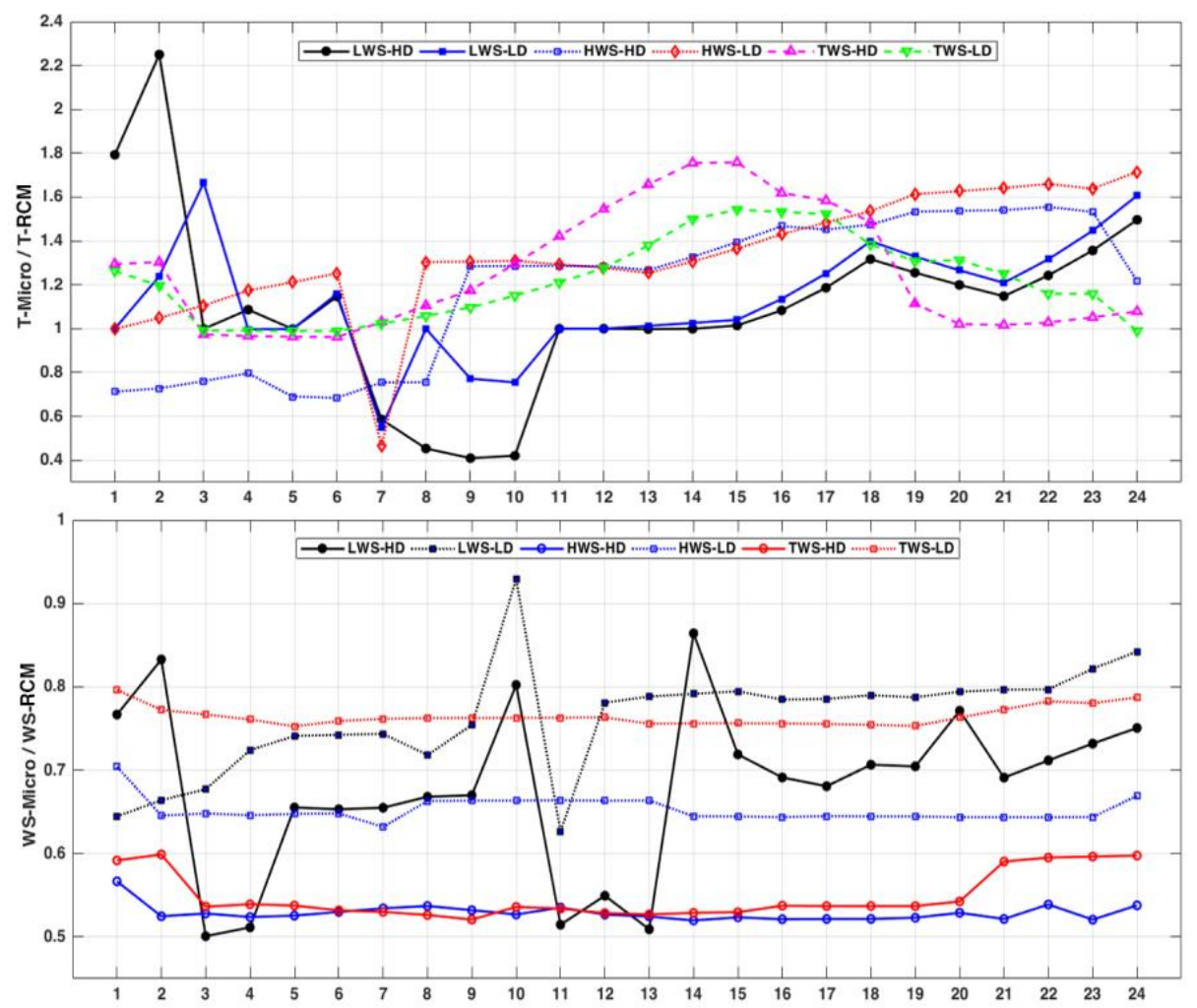

Figure 5. Normalized hourly air temperature (T) and wind speed (WS) at microscale as a function of mesoscale data (as inputs for CFD simulations). Typical wind speed (TWS): 19 February; lowest wind speed (LWS): 4 October; and highest wind speed (HWS): 15 January. HD: High density; LD: Low density.

The approach flow toward windward buildings with a high input wind speed (TWS and HWS) is distributed into the windward canopies in both urban models. However, due to high input wind speed magnitude, the approach wind is blocked by the windward buildings, and a large amount of flow skims over the top of the urban areas, instead of being distributed into the urban fabric. This causes lower average wind speed differences and $\Delta T$ between different locations in HD compared to the LD model. Moreover, in the denser urban areas, the blockage effect is notably higher. Consequently, the average wind speed in the main streets and canopies is lower compared to LD at the near-ground surfaces. The buoyancy effect in the hours with wind speed lower than $1 \mathrm{~m} / \mathrm{s}$ is much higher compared to high wind speeds in HWS and TWS, particularly in the urban canopies. Due to this high buoyancy effect, upward vortices occur in the canopies, which can cause lower air temperature by heat removal and thermal circulations. In the HD urban area, average wind speed out of all calculation points is considerably higher than in the LD area due to the channeling effect at urban canopies. In additions to urban comfort, this can affect total energy demand of the central building by changing average temperature (adjacent air to wall and surface) and heat transfer through walls, windows or infiltrations.

The hourly results of CFD simulations (wind speed, air temperature, air pressure, and relative humidity) were used to generate three weather data files to represent the typical and extreme high and low wind conditions in EPS. Here, air temperature at the microclimate level in most hours was amplified by urban morphology. Moreover, wind speed magnitude at the microclimate level was dampened in all hours of the day by urban morphology. Figure 6 illustrates the boxplot of Micro, RCM, and TMY wind speed and air temperature based on the generated weather datasets. The fluctuations of both wind speed and air temperature in each weather dataset imply the importance of considering microclimate data in EPS. The distribution of the wind speed and air temperature as two main influencing variables on the EPS notably differs from RCM data and particularly the TMY 
weather file as the most frequent weather data in the regular energy simulations. In the next section, adopting all generated weather data, the BPS results are presented.

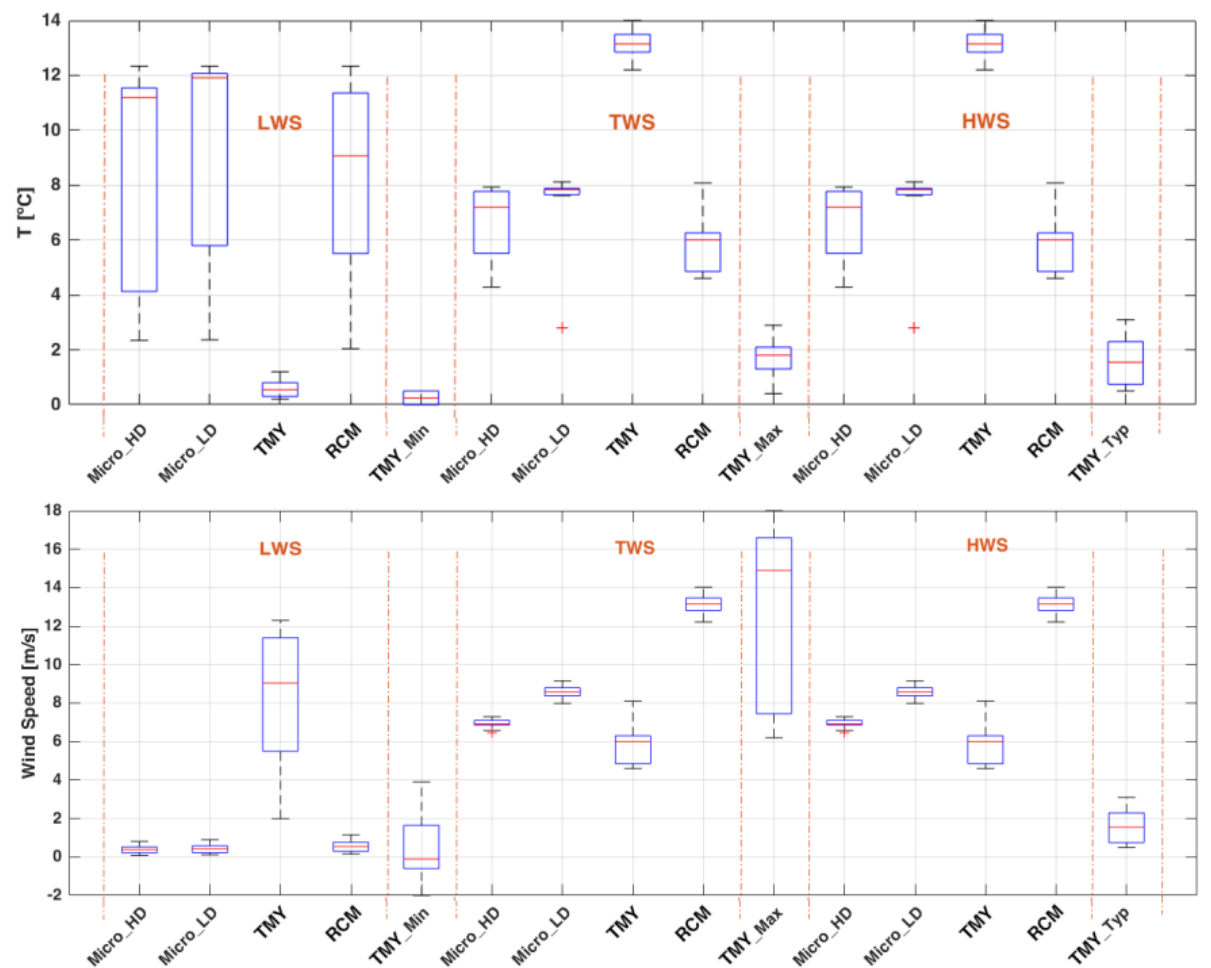

Figure 6. Boxplot of air temperature (up) and wind speed (down) out of Micro, RCM, and TMY data. TWS: 19 February; LWS: 4 October, HWS: 15 January; TMY-Typ: 14 September; TMY-Min: 17 November, and TMY-Max: 13 January. HD: High density; LD: Low density.

\subsection{Energy Performance Simulations (EPS)}

This section presents the results of the EPS out of Micro, RCM, and TMY weather data. For this purpose, the hourly outside surface temperature $\left(T_{S}\right)$, operative temperature $\left(T_{O}\right)$, and energy demand (heating and cooling) of the central building in both urban areas are presented. Figure 7 shows the hourly $T_{S}$ (average of all surfaces) of the central building based on the adopted weather data. In TWS, average $T_{S}$ adopting Micro data in $\operatorname{LD}\left(21.2^{\circ} \mathrm{C}\right)$ and $\mathrm{HD}\left(20.8^{\circ} \mathrm{C}\right)$ urban areas was $22 \%$ and $11 \%$ higher than with RCM data, while the average $T_{s}$ adopting the regular TMY file was $61 \%$ and $39 \%$ in the LD and HD areas, respectively, which is higher compared to Micro data. Moreover, the average $T_{S}$ in typical conditions in TMY data (TMY-Typ) was $89 \%$ and $82 \%$ higher than that of Micro data. These notable $T_{s}$ differences between TMY data and local microclimate data cause a high level of uncertainty in energy demand calculations. It can be noted that $T_{S}$ in typical conditions considering microclimate data is higher on average compared to other regular weather files. In LWS, average $T_{S}$ adopting Micro data (LD: $16.5^{\circ} \mathrm{C}, \mathrm{HD}: 15.1^{\circ} \mathrm{C}$ ) was slightly higher compared to the results with RCM and TMY data in $\mathrm{LD}(8 \%)$ and HD $(6 \%)$ areas. The extreme low wind conditions in TMY (TMY-Min) showed a $28 \%$ and $26 \%$ lower $T_{s}$ compared to adopting Micro data in LD and HD areas, respectively. According to the results, the average $T_{S}$ in LD areas was higher than in HD areas due to higher heat removal by upward vortices of wind in the canopies around the central buildings, as it was clear at CFD contours.

This is due to the higher buoyancy effect in the canopies around the central building in the HD area with the low-speed approaching wind. The $T_{s}$ difference between extreme low wind conditions in the local microclimate data and TMY-Min indicates that it is lower compared to that in TWS conditions. This can be due to differences between reference wind speed and wind direction in the RCM data used for CFD simulations. In HWS, microclimate data (LD: $10.5{ }^{\circ} \mathrm{C}, \mathrm{HD}: 9.8^{\circ} \mathrm{C}$ ) caused over $19 \%$ and $13 \%$ higher average $T_{s}$ compared to the results with RCM or TMY data in LD and HD areas, 
respectively. The extreme wind conditions in TMY (TMY-Max) showed about $87 \%$ and $77 \%$ lower average $T_{s}$ compared to considering microclimate data in the simulation process. In both typical and extreme conditions, the average and peak $T_{S}$ in LD areas were higher than in HD areas due to upward vortices in the northern and southern canopies around the central building. Moreover, the windward canopies amplify the approaching wind magnitude toward the center of the site, which also causes lower air temperature by heat removal. This air temperature is adjacent to the outside surface of the central building by changing the $T_{s}$ magnitude through convection heat transfer.
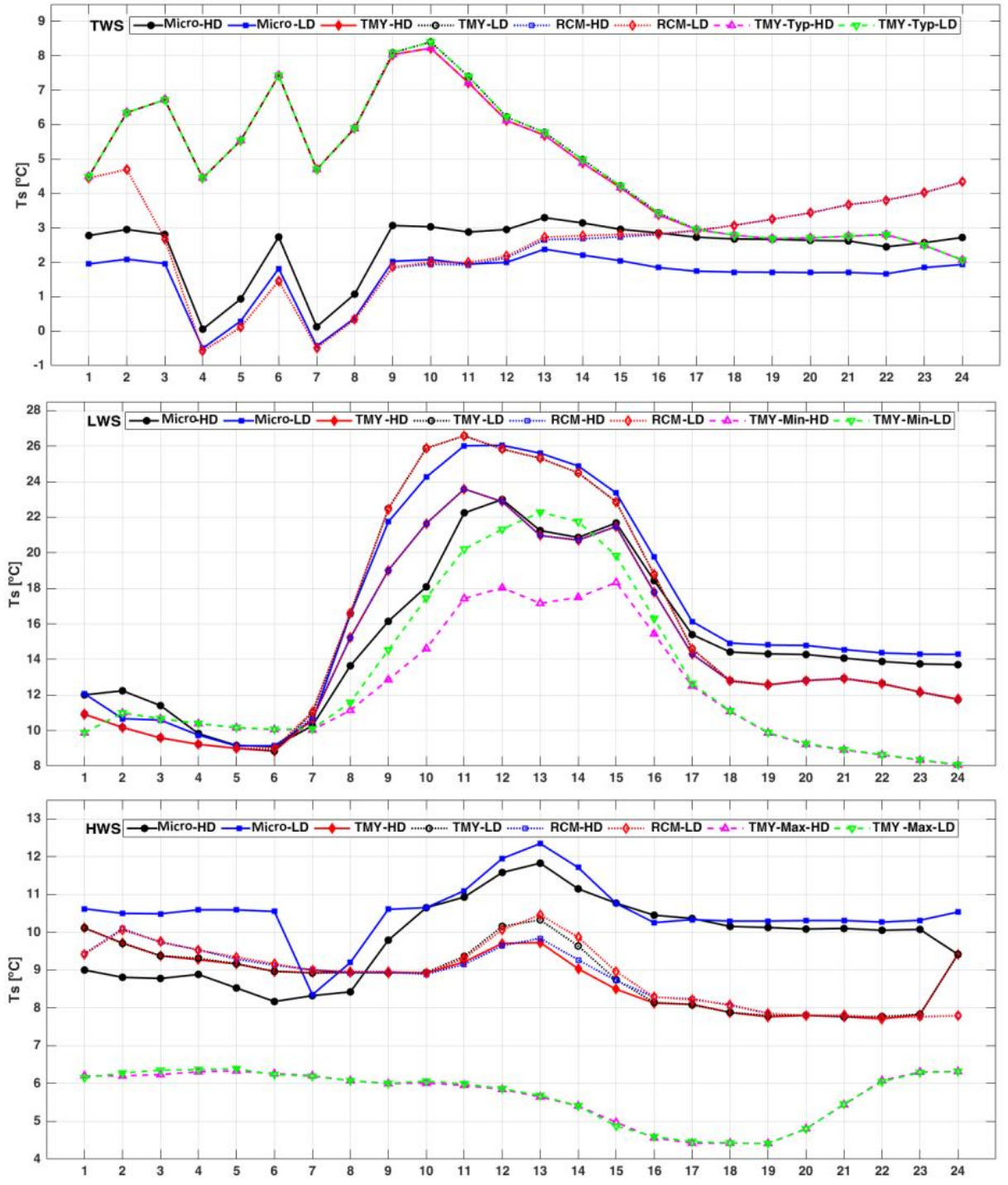

Figure 7. Hourly $T_{S}$ of all elevations of the central building in the LD and HD areas adopting fifteen weather datasets. TWS: 19 February; LWS: 4 October, HWS: 15 January; TMY-Typ: 14 September; TMY-Min: 17 November, and TMY-Max: 13 January. HD: High density; LD: Low density.

The outside $T_{S}$ differences between adopting Micro data for running EPS compared to RCM or TMY data induced higher heat transfer rates and, consequently, a higher indoor temperature. Figure 8 shows the hourly $T_{O}$ of the central buildings (average of all thermal zones) in LD and HD areas. The results of the $T_{O}$ were notably affected by the defined temperature set points of the Heating, Ventilation, and Air Conditioning (HVAC) system in the building (Section 3.3). In TWS, average $T_{O}$ adopting Micro data is over $1 \%$ and $3 \%$ higher than the results with RCM data in LD and HD areas, respectively. However, considering Micro data, the average $T_{O}$ is about $4 \%$ and $1 \%$ lower than the regular TMY file. The results showed over $7 \%$ lower $T_{O}$ considering Micro data compared to the typical conditions 
of TMY data (TMY-Typ) in both areas. In response to higher $T_{s}$ in LWS conditions, the average $T_{O}$ is slightly higher (about 1\%) adopting Micro data compared to the RCM and TMY data. The $T_{O}$ difference between Micro and TMY-Min data is a little bit higher, equivalent to $4 \%$. A similar trend can be observed in the HWS conditions, where the average $T_{O}$ is about $2 \%$ higher considering Micro data compared to the Meso, TMY, and TMY-Max. A slightly difference in $T_{O}$ results causes notable variations in calculating indoor thermal comfort and the total energy demand of the buildings. By considering extreme microclimate conditions in the simulation, average $T_{O}$ in all cases are higher compared to other regular weather datasets. Moreover, in response to higher outside air temperature and $T_{S}$ in most hours of the day, the average $T_{O}$ in LD areas with similar conditions is higher than in HD areas.
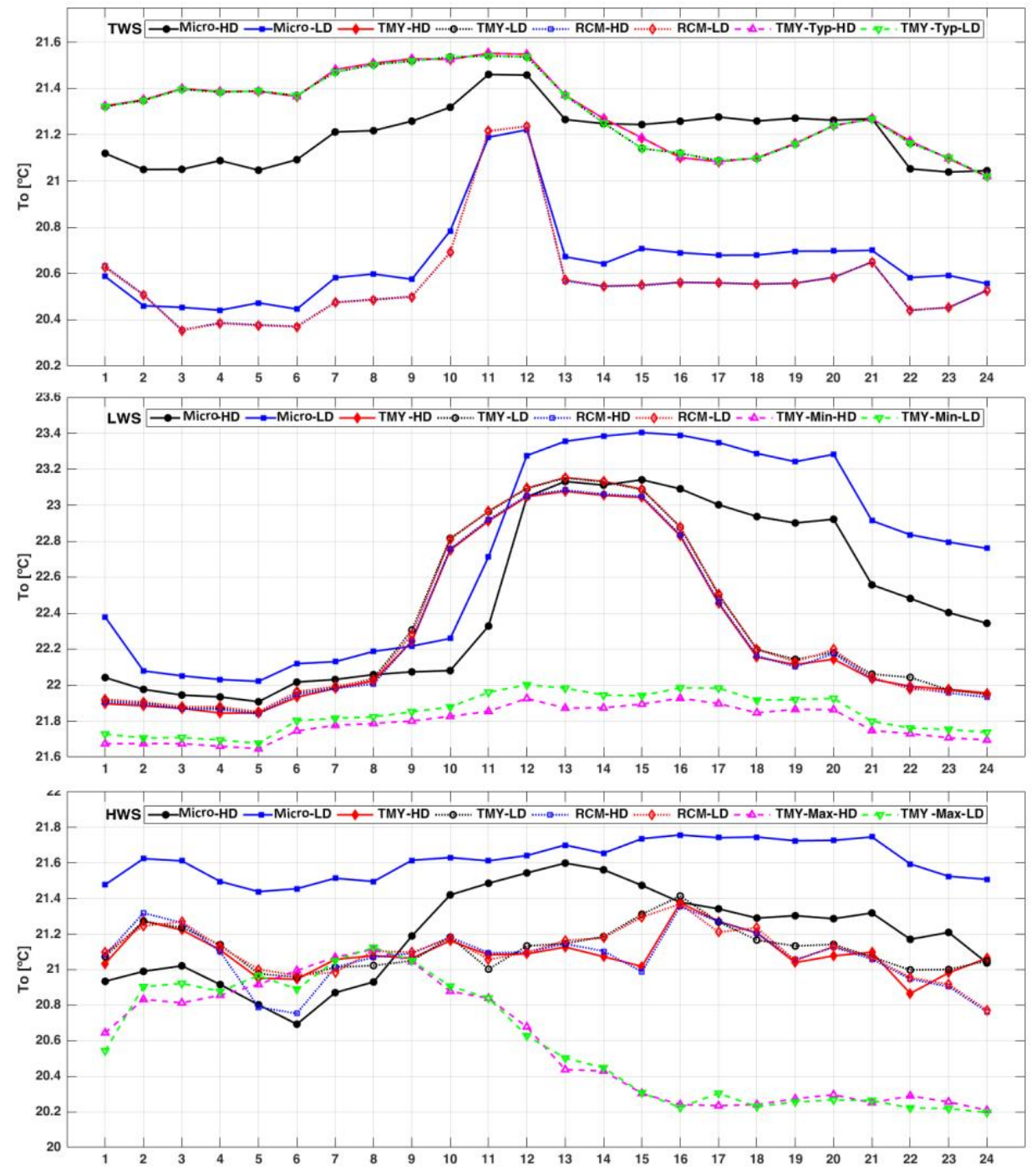

Figure 8. Hourly average $T_{o}$ of the central building in the LD and HD areas adopting fifteen weather datasets. TWS: 19 February; LWS: 4 October, HWS: 15 January; TMY-Typ: 14 September; TMY-Min: 17 November, and TMY-Max: 13 January. HD: High density; LD: Low density.

Figure 9 illustrates the boxplot of total energy demand (cooling and heating) of the central building in LD and HD areas adopting fifteen weather datasets. In TWS, Micro data compared to RCM data showed $2 \%$ and $6 \%$ lower energy demand in LD and HD, respectively, while compared to the TMY file on the same day, energy demand adopting Micro data was about $18 \%$ and $13 \%$ higher. These results indicate the high uncertainty in using regular TMY files to calculate energy demand for typical days. In LWS, average daily energy demand considering Micro data was $17 \%$ and $21 \%$ lower compared to 
the adopted RCM data in LD and HD areas. A similar trend and absolute values can be observed compared to the regular TMY file. However, the extreme low wind conditions in TMY (TMY-Min) showed $58 \%$ and $50 \%$ higher energy demand compared to Micro data in LD and HD areas, respectively. Interestingly, in HWS, energy demand adopting Micro data was 10\% and 14\% lower compared to RCM data and $10 \%$ and $13 \%$ lower compared to the regular TMY file. Adopting TMY-Max, results showed $15 \%$ and $18 \%$ higher energy demand compared to Micro data. The reason for lower energy demand in almost all cases using Micro data compared to RCM data (as input for the CFD simulations) was higher average outdoor air temperature and consequently higher $T_{s}$ and $T_{O}$. Moreover, energy demand in LD areas in almost all cases was higher than HD areas due to the heat removal in the canopies by higher wind speed around the central building.
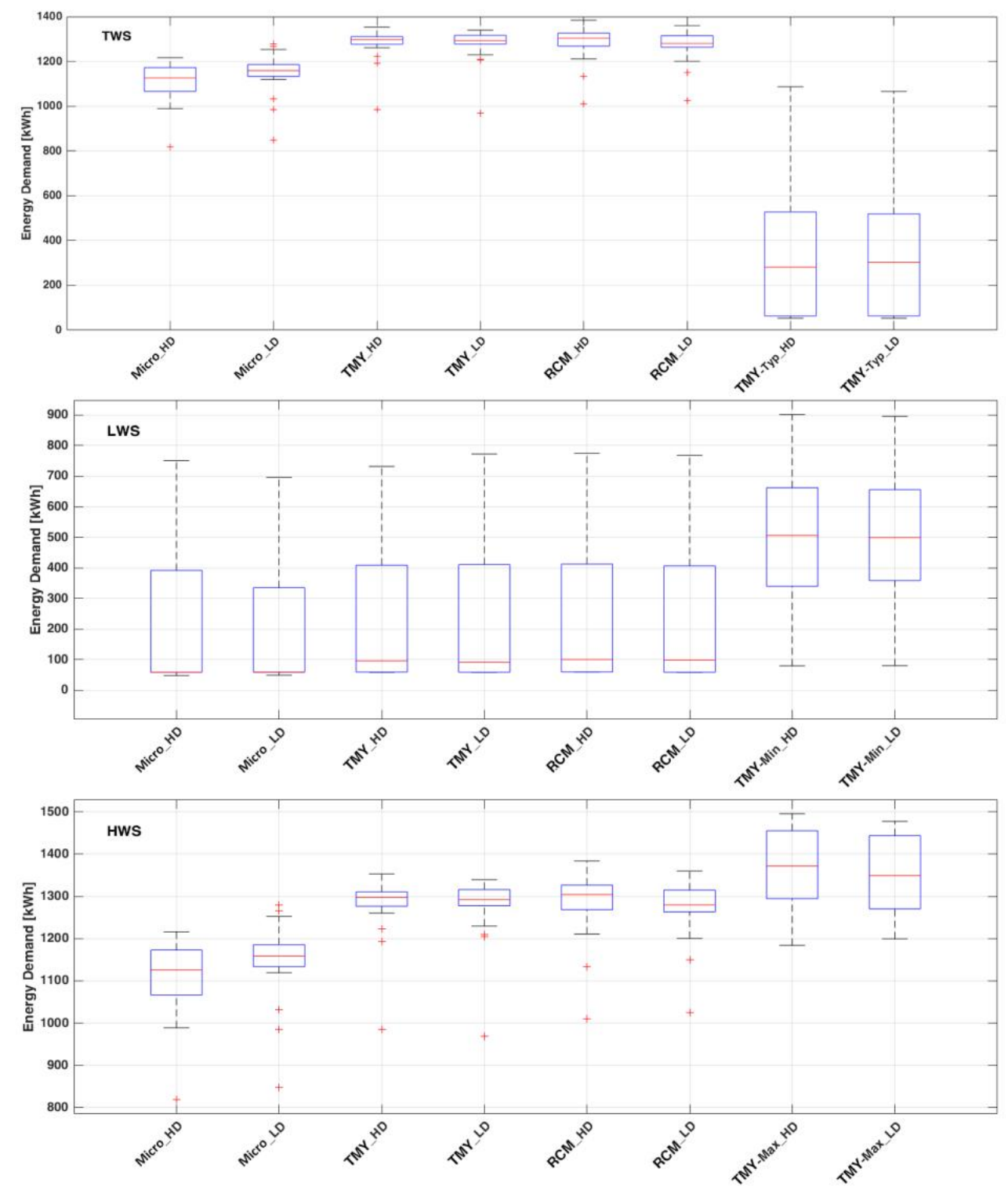

Figure 9. Boxplot of total energy demand (cooling and heating) of the central building in LD and HD areas adopting fifteen weather datasets. TWS: 19 February; LWS: 4 October, HWS: 15 January; TMY-Typ: 14 September; TMY-Min: 17 November, and TMY-Max: 13 January. HD: High density; LD: Low density.

The hourly peak demand in extreme conditions adopting Micro data differed from RCM and TMY files. For example, in LWS, the hourly peak energy demand adopting Micro data ( $695.3 \mathrm{kWh})$ was 
$10 \%, 11 \%$, and $13 \%$ lower compared to Meso, TMY, and TMY-Max, respectively, in the LD areas. These values in the HD areas were $4 \%, 2 \%$ and $15 \%$ (peak demand ith Micro data is $750.4 \mathrm{kWh}$ ). In HWS, peak energy demand with Micro data (1279.6 kWh) in the LD area was 6\%, 5\%, and $14 \%$ lower compared to Meso, TMY, and TMY-Max data, respectively. In the HD area, Micro data showed $1216.1 \mathrm{kWh}$ peak demand, which was 12\%, 11\%, and 5\% lower compared to Meso, TMY, and TMY-Max data. The peak load directly affects the efficiency of HVAC systems and consequently the total energy performance of the buildings, particularly during long-lasting extreme conditions. Table 2 integrates the comparison between microscale, mesoscale, and TMY data in percentages. In this table, negative values show reduction and posotive ones indicate higher values of the parameters at microscale compared to the two other sources. The integrated results showed that in response to higher $T_{S}$ and $T_{O}$, the total energy demand of the building showed higher values by considering the Micro data in the simulations.

Table 2. The comparison between Micro data with RCM data and the TMY file based on percentages.

\begin{tabular}{cccccccc}
\hline $\begin{array}{c}\text { Weather } \\
\text { Condition at } \\
\text { Microscale }\end{array}$ & $\begin{array}{c}\text { Urban } \\
\text { Area }\end{array}$ & \multicolumn{3}{c}{ RCM } & \multicolumn{4}{c}{ TMY (Typ, Min and Max) } \\
\cline { 3 - 8 } & LW & ED & $\boldsymbol{T}_{\boldsymbol{s}}$ & $\boldsymbol{T}_{\boldsymbol{o}}$ & ED & $\boldsymbol{T}_{\boldsymbol{s}}$ & $\boldsymbol{T}_{\boldsymbol{o}}$ \\
\hline \multirow{2}{*}{ TWS } & HD & $-2 \%$ & $+22 \%$ & $+1 \%$ & $-18 \%$ & $-61 \%$ & $-4 \%$ \\
\hline \multirow{2}{*}{ LWS } & LD & $-17 \%$ & $+8 \%$ & $+1 \%$ & $-58 \%$ & $+28 \%$ & $+4 \%$ \\
\hline \multirow{2}{*}{ HWS } & HD & $-21 \%$ & $+6 \%$ & $+1 \%$ & $-50 \%$ & $+26 \%$ & $+4 \%$ \\
\hline & LD & $-10 \%$ & $+19 \%$ & $+2 \%$ & $-15 \%$ & $+87 \%$ & $+2 \%$ \\
\hline
\end{tabular}

\subsection{Limitations}

Typical and extreme wind speeds in Stockholm in this study occur mostly during the cold season (January, February, September, October, and November); thus, the heating demand was the major energy demand affecting the calculations. Due to heavy calculation loads, the urban models in this study were simplified to only represent some major urban morphologies in Stockholm with extreme high and low built density. To limit the number of uncertainties in the CFD simulations, all buildings in these urban models have rectangular layouts and flat roof shapes. More detailed urban models are required to explore more sophisticated microclimate conditions. Results may vary by taking into account circular forms, different roof geometries, and more complex overall forms. Moreover, detailed moisture boundary conditions and moist air are not considered in the heat transfer models in the CFD simulations due to the high number of iterations.

\section{Conclusions}

In this study, the impacts of the urban microclimate conditions on the main influencing climate variables in the energy performance of the buildings were investigated, and the acquired microclimate data were taken into account in the calculation of outside surface temperature, operative temperature, and energy demand in comparison with other regular weather data files. Two urban models with a total area of $24,000 \mathrm{~m}^{2}$ with low and high density were generated to represent the urban morphology of Stockholm. These urban models had a twelve-story building in the center of the site, seven surrounding buildings, and one public green space. The building density, site coverage, final height, and overall form of each model was different to include the most influencing interactions of climatic variables in the CFD simulations. The inputs for CFD simulation were based on three synthesized mesoscale weather data for typical and extreme low and high wind conditions in Stockholm developed by Nik [43]. The interactions of wind flow and air temperature were evaluated at the micro level using ninety-nine defined calculation points in eleven locations of each model in nine height levels. The average values of wind speed, air temperature, air pressure, relative humidity, and heat flux out of these calculation 
points were used to generate three weather data with an hourly time-step for typical and extreme low and high wind conditions.

The generated weather data along with nine other weather datasets based on mesoscale metrological models and TMY file for EnergyPlus were adopted to study the overall energy performance of the buildings. In total, fifteen 24-h continuous weather data were developed and adopted to assess the energy performance of the central building in each urban area. According to the results, wind speed gets dampened and the air temperature gets amplified over $27 \%$ and $14 \%$ in both urban areas, respectively. Moreover, air pressure, relative humidity, and heat flux in the models are notably affected by microclimate conditions. In the low-density urban area, the average wind speed and turbulence intensity were lower compared to the high-density area. Moreover, air temperature in most hours was higher in the urban areas with lower density; however, in the dense urban area, due to the higher buoyancy effect in the low wind speeds, air temperature notably reduced by heat removal. By generating three weather datasets considering the fluctuations of these variables, the average and peak outside surface temperature and operative temperature showed over $67 \%$ and $7 \%$ higher magnitude, respectively, compared to other regular weather files. In response to higher surface and operative temperature, the average and peak energy demand of the central building in both urban areas showed over $21 \%$ variations. Moreover, due to the higher temperature in LD areas in both typical and extreme wind conditions, the central building in this area showed lower energy demand compared to the HD area. Furthermore, a reason for lower energy demand in the warmer urban areas was the periods in which typical and extreme wind conditions occur. All fifteen weather data were during colder seasons.

This work provided more evidence on the impacts of the microclimate conditions data on the average and peak energy performance of buildings by taking into account hourly microclimate data. Moreover, the simulations were conducted during several typical and extreme conditions, where notable differences were observed in extreme weather conditions compared to regular weather files. The developed method to generate hourly microclimate weather data for typical and extreme conditions has the possibility to reduce the calculation load while increasing the accuracy of the results. The generated weather datasets can represent microclimate conditions for noncomplex areas and can be adopted to normalize widely available weather files for Stockholm or cities with a similar climate for energy simulation studies. The database of the results, in addition to indicating the impacts of considering microclimate conditions on energy performance of buildings, can be used to design engineering applications such as HVAC systems based on more accurate estimations. The results can also initiate further investigations on the topic by considering more climate variables with an hourly time-step. As future research, more detailed urban models should take into account the detailed impacts of urban form on the microclimate conditions. Moreover, verifying the method with measured data in real urban areas is also targeted by the authors.

Author Contributions: Conceptualization and Methodology: K.J. and V.M.N.; Evaluations and Validation: K.J.; Results and Disscussions, Writing: K.J. and V.M.N.; Supervision: V.M.N.

Funding: This research was funded by the Swedish Research Council for Sustainable Development (Formas), grant number: 2016-20123.

Conflicts of Interest: The authors declare no conflict of interest.

\section{Nomenclature}

$\begin{array}{llll}\text { BPS } & \text { Building performance simulation } & \text { HD } & \text { High density } \\ \text { BMC } & \text { Building Modular Cells } & \text { LD } & \text { Low density } \\ \text { CC } & \text { cloud coverage } & \text { LWS } & \text { low wind speed } \\ \text { CFD } & \text { computational fluid dynamic } & \text { RCM } & \text { regional climate model } \\ \text { TMY } & \text { EnergyPlus Weather file } & \text { RH } & \text { Relative humidity } \\ \text { ED } & \text { Energy demand } & \text { TWS } & \text { Typical wind speed } \\ \text { GR } & \text { global radiation } & \text { T } & \text { Temperature }\left[{ }^{\circ} \mathrm{C}\right] \\ \text { HWS } & \text { high wind speed } & T_{S} & \text { Surface temperature }\end{array}$




\section{Appendix A}

Table A1. The main variables applied in the energy performance simulations.

\begin{tabular}{|c|c|c|c|c|}
\hline Variables & Description & \multicolumn{2}{|c|}{ Value } & Unit \\
\hline \multirow{8}{*}{ Loads } & \multirow{2}{*}{ People } & \multicolumn{2}{|c|}{0.2} & $\mathrm{p} / \mathrm{m}^{2}$ \\
\hline & & \multicolumn{2}{|c|}{ Schedule behavior } & As a simple office \\
\hline & \multirow{2}{*}{ Equipment } & \multicolumn{2}{|c|}{12} & $\mathrm{w} / \mathrm{m}^{2}$ \\
\hline & & \multicolumn{2}{|c|}{ Schedule behavior } & As a simple office \\
\hline & Lights & \multicolumn{2}{|c|}{12} & $\mathrm{w} / \mathrm{m}^{2}$ \\
\hline & Illumination & \multicolumn{2}{|c|}{500} & lux \\
\hline & Dimming & \multicolumn{2}{|c|}{ continuous } & - \\
\hline & Schedule behavior & \multicolumn{2}{|c|}{ As a simple office } & - \\
\hline \multirow{11}{*}{ Conditioning } & Heating (Set point: 20) & \multicolumn{2}{|c|}{100} & $\mathrm{w} / \mathrm{m}^{2}$ \\
\hline & Cooling (Set points: 25) & \multicolumn{2}{|c|}{100} & $\mathrm{w} / \mathrm{m}^{2}$ \\
\hline & Humidity control & \multicolumn{2}{|c|}{ No } & - \\
\hline & Fresh air & \multicolumn{2}{|c|}{2.5} & $\mathrm{~L} / \mathrm{s} /$ person \\
\hline & Fresh air & \multicolumn{2}{|c|}{0.3} & $\mathrm{~L} / \mathrm{s} /$ zone area $\mathrm{m}^{2}$ \\
\hline & Sensible recovery ratio & \multicolumn{2}{|c|}{0.7} & - \\
\hline & Heat recovery & \multicolumn{2}{|c|}{ None } & - \\
\hline & Scheduled & \multicolumn{2}{|c|}{ None } & - \\
\hline & Buoyancy driven flow & \multicolumn{2}{|c|}{$18-30$} & $\mathrm{C}$ \\
\hline & Rel. Humidity & \multicolumn{2}{|c|}{$80 \%$} & - \\
\hline & $\mathrm{ACH}$ & \multicolumn{2}{|c|}{0.2} & - \\
\hline \multirow{4}{*}{ Hot water } & Peak flow & \multicolumn{2}{|c|}{0.03} & $\mathrm{~m}^{3} / \mathrm{h} / \mathrm{m}^{2}$ \\
\hline & Supply Temp & \multicolumn{2}{|c|}{65} & $\mathrm{C}$ \\
\hline & Main Temp & \multicolumn{2}{|c|}{10} & $\mathrm{C}$ \\
\hline & Schedule behavior & \multicolumn{2}{|c|}{ As a simple office } & - \\
\hline & External walls & $\begin{array}{c}\text { Reinforced concrete, } \\
\text { plaster, insulation, mortar, } \\
\text { composite facade }\end{array}$ & $\begin{array}{l}\mathrm{U}=0.4 \\
\text { polystyrene insulation } \\
\text { according to NBC } 19 \text { Iran }\end{array}$ & $\mathrm{W} / \mathrm{m}^{2} \mathrm{~K}$ \\
\hline & Internal walls & Bricks, plaster, plaster & $\begin{array}{c}\mathrm{U}=0.7 \\
\text { No insulation }\end{array}$ & $\mathrm{W} / \mathrm{m}^{2} \mathrm{~K}$ \\
\hline & Roof & $\begin{array}{c}\text { Reinforced concrete, } \\
\text { plaster, insulation, cement } \\
\text { mosaic }\end{array}$ & $\begin{array}{l}\mathrm{U}=0.30 \\
\text { polystyrene insulation } \\
\text { according to NBC } 19 \text { Iran }\end{array}$ & $\mathrm{W} / \mathrm{m}^{2} \mathrm{~K}$ \\
\hline & Frame & Stainless steel & $\mathrm{U}=0.9$ & $\mathrm{~W} / \mathrm{m}^{2} \mathrm{~K}$ \\
\hline Construction & & Low-E & $\mathrm{U}=1.70(0.30)$ & $\mathrm{W} / \mathrm{m}^{2} \mathrm{~K}$ \\
\hline & & SHGC & 0.2 & - \\
\hline & Glass & Shading & None & - \\
\hline & & Projection Factor & $50 \%$ & - \\
\hline & & North facade & $25 \%$ & $9^{*}\left(2^{*} 2\right)$ win \\
\hline & & South façade & $15 \%$ & $5^{*}(2 * 2)$ win \\
\hline & Glazing & West façade & $8 \%$ & $3^{*}\left(2^{*} 2\right)$ win \\
\hline & & East façade & $8 \%$ & $3^{*}\left(2^{*} 2\right)$ win \\
\hline
\end{tabular}

\section{References}

1. Brockerhoff, M.; Nations, U. World Urbanization Prospects: The 2018 Revision. Popul. Dev. Rev. 2018, 24, 883. [CrossRef] 
2. United Nations Population Division, Department of Economic and Social Affairs. The Worlds Cities in 2018 Data Booklet; United Nations Population Division, Department of Economic and Social Affairs: New York, NY, USA, 2018.

3. IPCC. Climate Change 2014: Mitigation of Climate Change. Contribution of Working Group III to the Fifth Assessment Report of the Intergovernmental Panel on Climate Change; Edenhofer, O., Pichs-Madruga, R., Sokona, Y., Farahani, E., Kadner, S., Seyboth, K., Adler, A., Baum, I., Brunner, S., Eickemeier, P., et al., Eds.; Cambridge University Press: Cambridge, UK; New York, NY, USA, 2014.

4. Mahdavinejad, M.; Javanroodi, K. Natural ventilation performance of ancient wind catchers, an experimental and analytical study-case studies: One-sided, two-sided and four-sided wind catchers. Int. J. Energy Technol. Policy 2014, 10, 36. [CrossRef]

5. Antoniadou, P.; Papadopoulos, A.M. Occupants' thermal comfort: State of the art and the prospects of personalized assessment in office buildings. Energy Build. 2017, 153, 136-149. [CrossRef]

6. Griego, D.; Krarti, M.; Hernandez-Guerrero, A. Energy efficiency optimization of new and existing office buildings in Guanajuato, Mexico. Sustain. Cities Soc. 2015, 17, 132-140. [CrossRef]

7. Kubilay, A.; Derome, D.; Carmeliet, J. Coupling of physical phenomena in urban microclimate: A model integrating air flow, wind-driven rain, radiation and transport in building materials. Urban Clim. 2018, 24, 398-418. [CrossRef]

8. Hosham, A.F.; Kubota, T. Effects of Building Microclimate on the Thermal Environment of Traditional Japanese Houses during Hot-Humid Summer. Buildings 2019, 9, 22. [CrossRef]

9. Paramita, B.; Fukuda, H.; Perdana Khidmat, R.; Matzarakis, A. Building Configuration of Low-Cost Apartments in Bandung-Its Contribution to the Microclimate and Outdoor Thermal Comfort. Buildings 2018, 8, 123. [CrossRef]

10. Lai, D.; Liu, W.; Gan, T.; Liu, K.; Chen, Q. A review of mitigating strategies to improve the thermal environment and thermal comfort in urban outdoor spaces. Sci. Total Environ. 2019, 661, 337-353. [CrossRef]

11. Dernie, D.; Gaspari, J. Building Envelope Over-Cladding: Impact on Energy Balance and Microclimate. Buildings 2015, 5, 715-735. [CrossRef]

12. Zinzi, M.; Carnielo, E.; Mattoni, B. On the relation between urban climate and energy performance of buildings. A three-years experience in Rome, Italy. Appl. Energy 2018, 221, 148-160. [CrossRef]

13. Oke, T.R.; Mills, G.; Christen, A.; Voogt, J.A. Urban Climates; Cambridge University Press: Cambridge, UK, 2017. [CrossRef]

14. Li, H.; Zhou, Y.; Wang, X.; Zhou, X.; Zhang, H.; Sodoudi, S. Quantifying urban heat island intensity and its physical mechanism using WRF/UCM. Sci. Total Environ. 2019, 650, 3110-3119. [CrossRef] [PubMed]

15. Janjai, S.; Deeyai, P. Comparison of methods for generating typical meteorological year using meteorological data from a tropical environment. Appl. Energy 2009, 86, 528-537. [CrossRef]

16. Moazami, A.; Nik, V.M.; Carlucci, S.; Geving, S. Impacts of future weather data typology on building energy performance-Investigating long-term patterns of climate change and extreme weather conditions. Appl. Energy 2019, 238, 696-720. [CrossRef]

17. Wyszogrodzki, A.A.; Miao, S.; Chen, F. Evaluation of the coupling between mesoscale-WRF and LES-EULAG models for simulating fine-scale urban dispersion. Atmos. Res. 2012, 118, 324-345. [CrossRef]

18. Golden, J.S.; Kaloush, K.E. Mesoscale and microscale evaluation of surface pavement impacts on the urban heat island effects. Int. J. Pavement Eng. 2006, 7, 37-52. [CrossRef]

19. Kondo, H.; Tokairin, T.; Kikegawa, Y. Calculation of wind in a Tokyo urban area with a mesoscale model including a multi-layer urban canopy model. J. Wind Eng. Ind. Aerodyn. 2008, 96, 1655-1666. [CrossRef]

20. Santiago, J.L.; Krayenhoff, E.S.; Martilli, A. Flow simulations for simplified urban configurations with microscale distributions of surface thermal forcing. Urban Clim. 2014, 9, 115-133. [CrossRef]

21. Li, X.; Mitra, C.; Dong, L.; Yang, Q. Understanding land use change impacts on microclimate using Weather Research and Forecasting (WRF) model. Phys. Chem. Earth 2018, 103, 115-126. [CrossRef]

22. Mauree, D.; Naboni, E.; Coccolo, S.; Perera, A.T.D.; Nik, V.M.; Scartezzini, J.-L. A review of assessment methods for the urban environment and its energy sustainability to guarantee climate adaptation of future cities. Renew. Sustain. Energy Rev. 2019, 112, 733-746. [CrossRef]

23. Futcher, J.A.; Mills, G. The role of urban form as an energy management parameter. Energy Policy 2013, 53, 218-228. [CrossRef] 
24. Shimazaki, Y.; Yoshida, A.; Suzuki, R.; Kawabata, T.; Imai, D.; Kinoshita, S. Application of human thermal load into unsteady condition for improvement of outdoor thermal comfort. Build. Environ. 2011, 46, 1716-1724. [CrossRef]

25. Alcazar, S.S.; Olivieri, F.; Neila, J. Green roofs: Experimental and analytical study of its potential for urban microclimate regulation in Mediterranean-continental climates. Urban Clim. 2016, 17, 304-317. [CrossRef]

26. Athamena, K.; Sini, J.-F.; Rosant, J.-M.; Guilhot, J. Numerical coupling model to compute the microclimate parameters inside a street canyon: Part II: Experimental validation of air temperature and airflow. Sol. Energy 2018, 170, 470-485. [CrossRef]

27. Toparlar, Y.; Blocken, B.; Vos, P.; van Heijst, G.J.F.; Janssen, W.D.; van Hooff, T.; Timmermanse, H.J.P.; Montazeria, H. CFD simulation and validation of urban microclimate: A case study for Bergpolder Zuid, Rotterdam. Build. Environ. 2015, 83, 79-90. [CrossRef]

28. Tien, P.W.; Calautit, J.K. Numerical analysis of the wind and thermal comfort in courtyards "skycourts" in high rise buildings. J. Build. Eng. 2019, 24, 100735. [CrossRef]

29. Toparlar, Y.; Blocken, B.; Maiheu, B.; van Heijst, G.J.F. A review on the CFD analysis of urban microclimate. Renew. Sustain. Energy Rev. 2017, 80, 1613-1640. [CrossRef]

30. Perini, K.; Magliocco, A. Effects of vegetation, urban density, building height, and atmospheric conditions on local temperatures and thermal comfort. Urban For. Urban Green. 2014, 13, 495-506. [CrossRef]

31. Hargreaves, A.; Cheng, V.; Deshmukh, S.; Leach, M.; Steemers, K. Forecasting how residential urban form affects the regional carbon savings and costs of retrofitting and decentralized energy supply. Appl. Energy 2017, 186, 549-561. [CrossRef]

32. Ouketta, S.; Bouchahm, Y. Numerical evaluation of urban geometry's control of wind movements in outdoor spaces during winter period. Case Mediterr. Clim. Renew. Energy 2020, 146, 1062-1069. [CrossRef]

33. Chen, Y.; Hong, T.; Piette, M.A. Automatic generation and simulation of urban building energy models based on city datasets for city-scale building retrofit analysis. Appl. Energy 2017, 205, 323-335. [CrossRef]

34. Chen, Y.; Hong, T.; Luo, X.; Hooper, B. Development of city buildings dataset for urban building energy modeling. Energy Build. 2019, 183, 252-265. [CrossRef]

35. Botham-Myint, D.; Recktenwald, G.W.; Sailor, D.J. Thermal footprint effect of rooftop urban cooling strategies. Urban Clim. 2015, 14, 268-277. [CrossRef]

36. Kantzioura, A.; Kosmopoulos, P.; Zoras, S. Urban surface temperature and microclimate measurements in Thessaloniki. Energy Build. 2012, 44, 63-72. [CrossRef]

37. Zhang, J.; Xu, L.; Shabunko, V.; Tay, S.E.R.; Sun, H.; Lau, S.S.Y.; Reindl, T. Impact of urban block typology on building solar potential and energy use efficiency in tropical high-density city. Appl. Energy 2019, 240, 513-533. [CrossRef]

38. Kikumoto, H.; Ooka, R.; Han, M.; Nakajima, K. Consistency of mean wind speed in pedestrian wind environment analyses: Mathematical consideration and a case study using large-eddy simulation. J. Wind Eng. Ind. Aerodyn. 2018, 173, 91-99. [CrossRef]

39. Zhang, J.; $\mathrm{Wu}, \mathrm{L}$. The influence of population movements on the urban relative humidity of Beijing during the Chinese Spring Festival holiday. J. Clean. Prod. 2018, 170, 1508-1513. [CrossRef]

40. Giridharan, R.; Emmanuel, R. The impact of urban compactness, comfort strategies and energy consumption on tropical urban heat island intensity: A review. Sustain. Cities Soc. 2018, 40, 677-687. [CrossRef]

41. Braulio-Gonzalo, M.; Bovea, M.D.; Ruá, M.J.; Juan, P. A methodology for predicting the energy performance and indoor thermal comfort of residential stocks on the neighbourhood and city scales. A case study in Spain. J. Clean. Prod. 2016, 139, 646-665. [CrossRef]

42. Trihamdani, R.A.; Lee, S.H.; Kubota, T.; Phuong, T.T. Configuration of Green Spaces for Urban Heat Island Mitigation and Future Building Energy Conservation in Hanoi Master Plan 2030. Buildings 2015, 5, 933-947. [CrossRef]

43. Elghonaimy, I.; Mohammed, E.W. Urban Heat Islands in Bahrain: An Urban Perspective. Buildings 2019, 9, 96. [CrossRef]

44. Khoshdel Nikkho, S.; Heidarinejad, M.; Liu, J.; Srebric, J. Quantifying the impact of urban wind sheltering on the building energy consumption. Appl. Therm. Eng. 2017, 116, 850-865. [CrossRef]

45. Wang, B.; Cot, L.D.; Adolphe, L.; Geoffroy, S.; Sun, S. Cross indicator analysis between wind energy potential and urban morphology. Renew. Energy 2017, 113, 989-1006. [CrossRef] 
46. Allegrini, J.; Dorer, V.; Carmeliet, J. Influence of morphologies on the microclimate in urban neighbourhoods. J. Wind Eng. Ind. Aerodyn. 2015, 144, 108-117. [CrossRef]

47. Mittal, H.; Sharma, A.; Gairola, A. A review on the study of urban wind the pedestrian level around buildings. J. Build. Eng. 2018, 18, 154-163. [CrossRef]

48. Shirzadi, M.; Naghashzadegan, M.; Mirzaei, P.A. Developing a framework for improvement of building thermal performance modeling under urban microclimate interactions. Sustain. Cities Soc. 2019, 44, 27-39. [CrossRef]

49. Javanroodi, K.; Mahdavinejad, M.; Nik, V.M. Impacts of urban morphology on reducing cooling load and increasing ventilation potential in hot-arid climate. Appl. Energy 2018, 231, 714-746. [CrossRef]

50. Nik, V.M. Making energy simulation easier for future climate-Synthesizing typical and extreme weather data sets out of regional climate models (RCMs). Appl. Energy 2016, 177, 204-226. [CrossRef]

51. Nik, V.M. Application of typical and extreme weather data sets in the hygrothermal simulation of building components for future climate-A case study for a wooden frame wall. Energy Build. 2017, 154, 30-45. [CrossRef]

52. Weather Data EnergyPlus. Available online: https://energyplus.net/weather (accessed on 24 June 2019).

53. Al-Sallal, K.A.; Al-Rais, L. Outdoor airflow analysis and potential for passive cooling in the traditional urban context of Dubai. Renew. Energy 2011, 36, 2494-2501. [CrossRef]

54. Javanroodi, K.; Nik, V.M.; Mahdavinejad, M. A novel design-based optimization framework for enhancing the energy efficiency of high-rise office buildings in urban areas. Sustain. Cities Soc. 2019, 49, 101597. [CrossRef]

55. Solemma LLC. Available online: https://www.solemma.com/ (accessed on 25 June 2019).

(C) 2019 by the authors. Licensee MDPI, Basel, Switzerland. This article is an open access article distributed under the terms and conditions of the Creative Commons Attribution (CC BY) license (http://creativecommons.org/licenses/by/4.0/). 